\title{
Mollusk Habitats and Fisheries in Kiribati: An Assessment from the Gilbert Islands ${ }^{1}$
}

\author{
Frank R. Thomas ${ }^{2}$
}

\begin{abstract}
Biological and ecological attributes of 24 species of edible bivalves and gastropods from the Gilbert Islands Group, Kiribati, Micronesia, were assessed for their resilience by examining size at maturity, intertidal burying, adjacent subtidal populations, benthic mobility, and larval type. Foraging for mollusks is largely confined to the intertidal and shallow subtidal regions, although modern diving gear and outboard motors now provide human foragers access to offshore resources. Changes brought about by human demographic pressures have resulted in overexploitation of a number of molluscan resources. It is suggested that the sustainable use of invertebrates and other marine species for food and nonfood purposes in Kiribati rests on a remodeled form of marine tenure.
\end{abstract}

Atolls present a variety of marine environments and molluscan resources that have provided subsistence living to generations of Pacific islanders (Tebano et al. 1993, Taniera 1994). Kiribati (Figure 1) is but one of more than 20 nations in the Pacific, each of which possessed a rich inshore fisheries tradition and lore. In recent years, however, traditional ecological knowledge (TEK) has suffered the inevitable decline that characterizes similar bodies of knowledge throughout most of Oceania. High human population density, urban drift, more efficient extractive technologies, and expanding market opportunities all have inevitably affected the ocean resources of these islands. In this study, I examined the prey biology and ecology of mollusk fisheries in Kiribati, Gilbert Islands, looking at factors distinguishing vulnerable

\footnotetext{
${ }^{1}$ Financial support from the University of Hawai'i's Arts and Sciences Advisory Council; funds provided by Alison Kay through a University of Hawai'i Foundation Grant and Research Assistantship; Sigma Xi (The Scientific Research Society) Grant-in-Aid of Research nos. 2710 and 8326; the Hawaiian Malacological Society; two grants from Conchologists of America, Inc.; and travel funds provided by Temakei Tebano at the University of the South Pacific. Manuscript accepted 1 February 2000.

${ }^{2}$ Ogden Environmental and Energy Services, 680 Iwilei Road, Suite 660, Honolulu, Hawai'i 96817.
}

Pacific Science (2001), vol. 55, no. 1:77-97

(C) 2001 by University of Hawai'i Press

All rights reserved from resilient resources, and their effect on subsistence.

Can traditional ecological knowledge be wedded with modern technology to revive the fisheries? Because the thrust of this paper is limited to prey biology and ecology in the context of mollusk fisheries, details of analytic methodology related to foraging efficiency are not discussed here, but can be found in Thomas (1999).

Data on molluscan resources of the Gilbert Islands date back to the 1950 s when Banner and Randall (1952) described the invertebrates of Onotoa Atoll, but identifications were poor and there were few detailed descriptions of exploitive strategies. A major interdisciplinary environmental survey on the main atoll of Tarawa, Republic of Kiribati (Abbott and Garcia 1995), expanded species identification and habitat description, and provided an assessment of the impact of human activities (Figure 2). The Tarawa Lagoon Project of 1992-1994 (Paulay 1995) is a major study of the lagoon, and data from that project are included in this study.

\section{MATERIALS AND METHODS}

Several communities engaged in subsistence and commercial exploitation of mollusks were investigated intermittently between 1993 and 1998. Research focused on four atolls in the central Gilberts: Abaiang, Tarawa (both urbanized and rural sectors), Maiana, and Abe- 


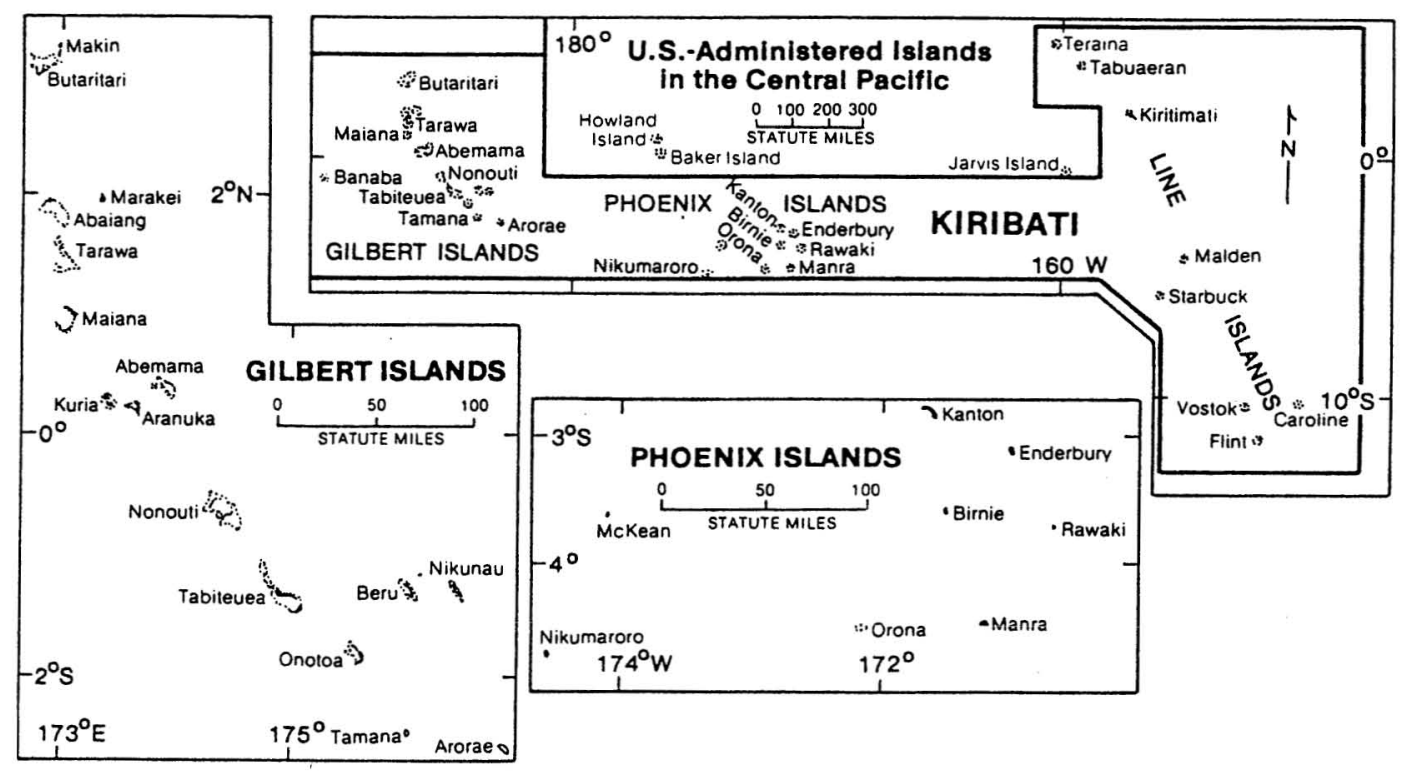

Figure 1. The Republic of Kiribati (modified from Motteler 1986:16; reprinted with permission from Bishop Museum Press, Honolulu, Hawai'i).

mama, and one atoll in the Southern Group, Tabiteuea North (Thomas 1999). Data on various aspects of mollusk gathering were obtained by participant observation, interviews, and from the Shellfish Gatherer Survey (SGS) of the Tarawa Lagoon Project (TLP), in cooperation with BioSystems, Inc., of Santa Cruz, California.

I accompanied foragers, both individuals and groups, on 73 foraging trips covering 69 days, for a total of $139.63 \mathrm{hr}$ of direct observation (286.92 forager-hours). Mean group size was 2.6 foragers $(\mathrm{SD}=0.9, n=146$ ). Fifty-nine different individuals took part in these activities. When it was not possible to record foraging activities directly, the relevant information was elicited via interviews. A total of 65 foraging trips was recorded over a period of 51 days, for an estimated total of $88.5 \mathrm{hr}$ of foraging effort (161 forager-hours). Mean group size was 3.1 foragers $(\mathrm{SD}=0.7$, $n=148)$. A total of 19 different individuals was interviewed.

Information was also derived from data sheets made available by personnel of the TLP. These data originated from landings along the southern portion of Tarawa Atoll, with samples taken between December 1992 and February 1994. This information greatly expanded the sample size of foraging events, with 83 foraging trips covering 26 days and approximately $191 \mathrm{hr}$ of foraging time (257 forager-hours). Mean group size was 1.3 foragers $(\mathrm{SD}=0.7, n=112)$.

Prey type identifications and basic habitat information are based on Cernohorsky (1971, 1972), Eisenberg (1981), Abbott and Dance (1982), Paulay (1995), and personal observations. For each prey type, five factors were examined to assist in distinguishing vulnerable from resilient resources: (1) size at maturity; (2) intertidal burying; (3) adjacent subtidal populations; (4) benthic mobility; and (5) larval type (see Catterall and Poiner 1987). In a number of cases, the description of relevant properties was limited, reflecting gaps in the data.

\section{Atoll Zonation and Molluscan Patch Types}

From windward to leeward (Figure 3), the basic zones and molluscan patch types char- 


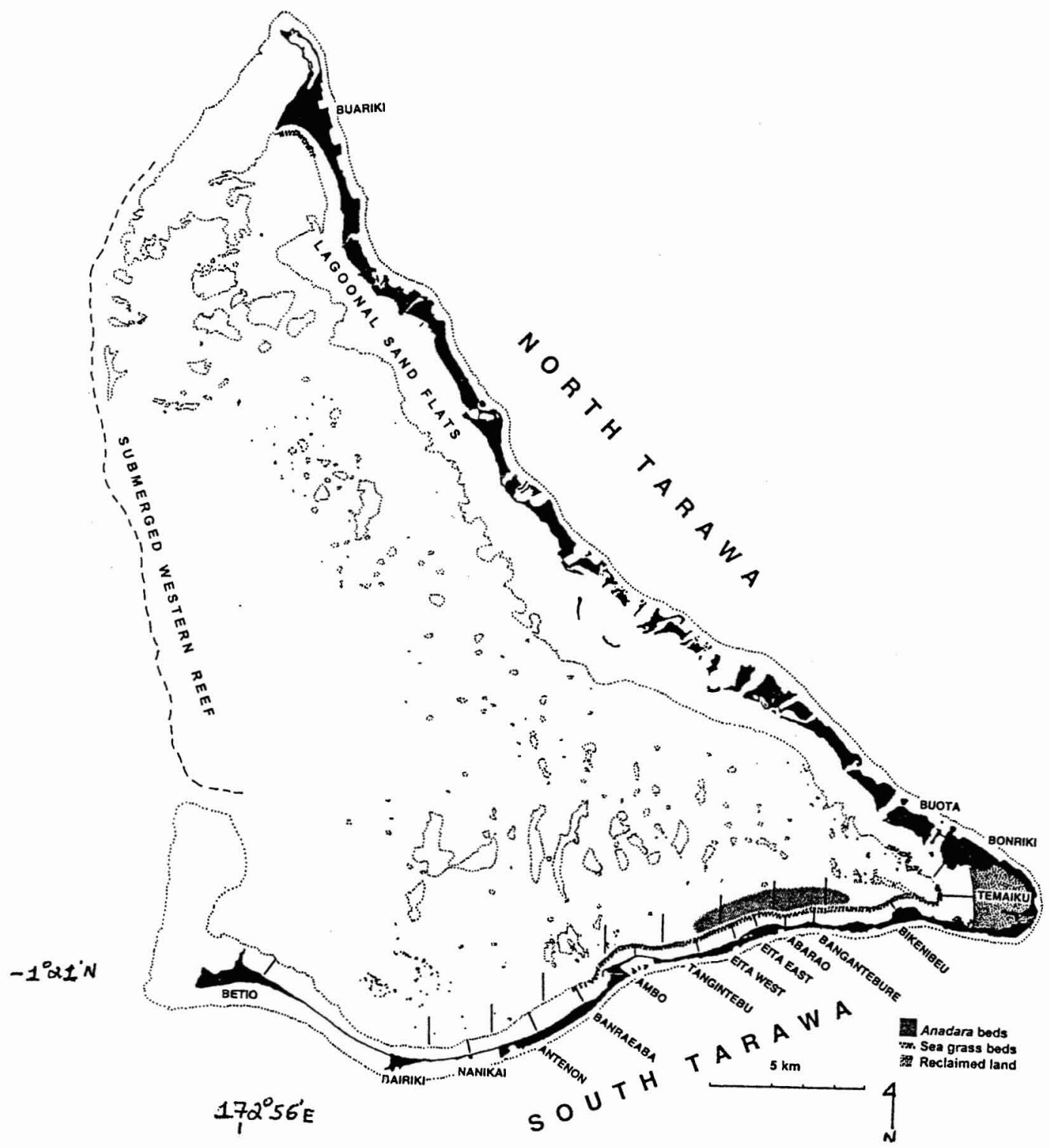

Figure 2. Tarawa Atoll (modified from Paulay 1997: fig. 1; reprinted with permission from Gustav Paulay).

acteristic of the open atolls of the Gilbert Islands are the: (1) reef slope; (2) submarine terrace; (3) reef front; (4) reef margin; (5) moat; (6) reef crest; (7) reef flat; (8) shoreline; (9) lagoon reef flat including mangrove, sand flats, and sea grass beds; (10) lagoon slope and floor; and (11) leeward reef.
THE SEAWARD REEF: The seaward reef slope descends steeply from the upper limit of vigorous hermatypic corals at a depth of about $18 \mathrm{~m}$ to the deepest seaward portion of the reef between 4000 and $6000 \mathrm{~m}$. In the Gilberts, little is known of the biota below $40 \mathrm{~m}$, but mollusks commonly found in the 


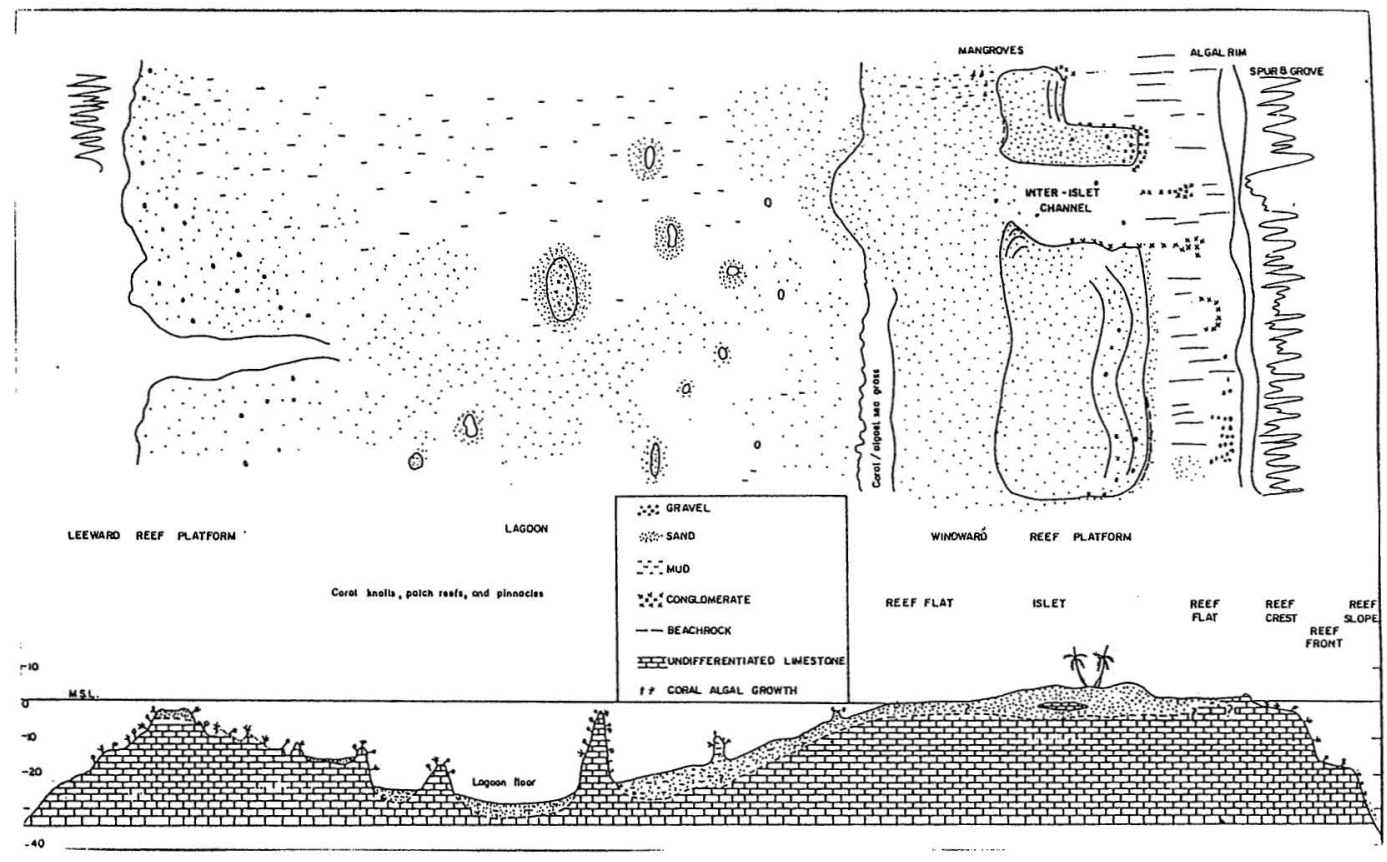

FIGURE 3. Schematic diagram of atoll features of the Gilbert Islands (modified from Richmond 1993:17, fig. 5; reprinted with permission from the South Pacific Applied Geoscience Commission [SOPAC]).

upper reaches of this zone include Pinctada and Trochus (Wells 1957), which also occur on the submarine terraces between depths of 15 and $18 \mathrm{~m}$. The dominant mollusks on the reef front, the shoreward face of the seaward reef slope where coral growth is sparse and heavy surf dominates, are gastropods such as Patella and Trocbus (Demond 1957). The seaward reef margin, distinguished by spurand-groove formations, which disperse and channel ocean water, supports compact and encrusting corals and coralline algae such as Porolithon. Mollusks found in this zone include Trocbus, Turbo, Cypraea, and Drupa (Wells 1957, Zann 1982). Shoreward of the seaward reef margin are moats, areas of shallow water normally awash even at extreme low tide. In many respects, moats resemble lagoon habitats, except for the hard bottom of coralline rock or gravel. Thick-branching Acropora and Heliopora are the dominant corals, and the mollusks include Cypraea, Conus, Lambis, Hippopus bippopus, and Tridacna gigas in the deeper sections (Wells 1957). The reef crest, a high-energy environment, demarcates the seaward limit of the reef flat; it supports the gastropod Turbo setosus. The reef flat itself is commonly exposed or barely awash at lowest tide. It consists of a truncated floor zoned by the tides, which effect varying degrees of exposure and temperature between seaward edge and inshore margin. The surface of the reef flat supports Cypraea, Thais, Trochus, Turbo, and other species of gastropods adapted primarily as crab predators and to the force of waves (Banner and Randall 1952).

The shoreline of islets (motus) on both lagoon and ocean sides consists of both cemented and uncemented topographic features. Beachrock, lithified beach sand and coral debris, and conglomerates, cemented storm deposits between 1 and $2 \mathrm{~m}$ above low-tide level, are occupied by dense concentrations of the gastropod Nerita plicata, adapted to withstand heat and desiccation, as well as rain (Cloud 1952). Moderately to poorly sorted medium sand, gravel, and cobbles that rise with a relatively sharp change in slope above the reef flat harbor the bivalves 
Asaphis violascens and the small beach clam Atactodea striata. The latter is also locally abundant in other intertidal sandy areas.

THE LAGOON: Lagoon beaches tend to be well to moderately sorted, from fine sand to gravel; highest elevation is generally less than $1 \mathrm{~m}$ above the highest tide; and sand spits are a common feature, especially near interislet channels and as lagoon-directed seawardproduced growth at the ends of the atolls. Asaphis violascens and Atactodea striata are common in this zone (Paulay 1995).

The lagoon reef flat is typically a depositional surface built up by ocean-to-lagoon sediment transport. Sediments tend to be poorly sorted with some silt. The reef flats are generally better developed along the sections facing the prevailing winds than elsewhere and are zoned as are the windward reef flats. The reef flat is primarily intertidal, grading into subtidal zones toward the center of the lagoon. Except during periods of westerly storms, waters are generally calm. Mangroves, mainly Rhizophora mucronata, may rim the shoreline. The sediments associated with mangroves are characteristically soft, of sand mixed with rich organic matter. Fiddler crabs, $U c a$ sp., and stomatopod burrows occur in transitional areas between the mangrove sediments and the sand flats. The bivalve Gafrarium pectinatum is occasionally found in the mangroves.

Sand flats are the most extensive habitat on the lagoon reef flat. The fauna varies with depth of the water, size of sand particles, amount of wave action, and depth of the sand. This habitat supports the economically important Anadara uropygmelana, Strombus $l u$ buanus, and Gafrarium pectinatum (Paulay 1995). The low intertidal and subtidal regions of the lagoon border may support extensive beds of Thalassia hemprichii that stabilize and bind fine sand and silt rich in organic matter. The sea grass beds are productive grounds for Anadara uropygmelana, Trachycardium angulatum, Gafrarium pectinatum, Timoclea marica, Strombus lubuanus, and other mollusks (Paulay 1995).

Atoll lagoons in the Gilberts encompass a much larger area than the landmass. They vary from an almost enclosed lagoon at Marakei to poorly defined shallow expanses at Nonouti and Tabiteuea. The deepest lagoon, at Butaritari, at $33 \mathrm{~m}$ is shallower than atoll lagoons in the Marshalls and Tuvalu. Deep reef passes are restricted to leeward lagoon margins. There is an increase in live coral coverage and decrease in sediment coverage toward the leeward margin. The lagoon slope, predominantly covered with sand or coral rubble, begins at the deepest edge of the sea grass bed, approximately $0.5 \mathrm{~m}$ deep at low tide. It slopes gently to depths of $8-10 \mathrm{~m}$ at $1 \mathrm{~km}$ from the sea grass margin, if present. This area supports scattered colonies or clumps of primarily Porites spp. and Pocillopora damicornis in South Tarawa. Mollusks such as Anadara uropygmelana and psammophilic crustaceans and echinoids predominate (Wells 1957, Paulay 1995) on fringing or patch reefs often dominated by Acropora on the lagoonal slope in North Tarawa.

The lagoon floor is the more or less level bottom of a lagoon. Sandbars, pinnacles, coral knolls, and patch reefs (dead and living) present sharp irregularities in the bottom. Lagoon depth, sedimentation rates, and other physical factors affect the growth of coral and thus species density and diversity. Mollusks are uncommon and constitute only a small fraction of the biomass on Tarawa. The leeward reef platform is characterized by irregular outer reefs and few or no islets. Leeward reefs are commonly submerged over most of their area, even at low tide, and show relatively vigorous coral growth. This zone supports Lambis and Tridacna. The seaward slope is generally much steeper than on windward reefs. As with the seaward (windward) reef slope and submarine terrace, Trochus and Pinctada may be abundant (Wells 1957).

TIDES AND CURRENTs: The greatest tidal fluctuations (spring tides) occur on the days of full and new moons; the smallest fluctuations (neap tides) are about halfway between spring tides, during the first and last quarters. In Tarawa Lagoon, semidiurnal tides have a mean amplitude of $1.5 \mathrm{~m}$ (neap range, $1.2 \mathrm{~m}$; spring range, $1.8 \mathrm{~m}$ ) (Gillie 1993). Fluctuations in sea level (on the order of $10-20 \mathrm{~cm}$ ) follow seasonal changes in the location and strength of the trade winds. During the El Niño event in 1982-1983, the monthly mean 
sea level was $28 \mathrm{~cm}$ above the long-term mean in 1982, but $21 \mathrm{~cm}$ below mean in late 1983. Repeated cycles of submergence and exposure and variation along these lines as a result of lunar periodicity make the intertidal a zone of high environmental stress.

\section{Foraging}

The indigenous Micronesian population considers many species of mollusks edible, but only a handful appear to be specifically targeted. Only 24 of the perhaps 1000 or more species that may occur in the Gilbert Islands (see Kay and Johnson [1987] for the numbers estimated from the Marshall Islands) composed the major "crop" in this study.

A foraging bout usually takes place within a single patch type, for example, a sand flat, sea grass bed, or nearshore biotope. Most households on Tarawa and other atolls are concentrated on the lagoon side of the motu and harvest mollusks and other resources from this habitat. Where sea grass beds occur, they are the focus of the most intensive gathering pressure (Paulay 1995). Women and children concentrate on resources in the intertidal and shallow subtidal areas where they can easily located telltale marks of their prey. Offshore diving is an activity carried out by male divers only. Limited ocean-side gathering does take place, however.
The higher in-patch returns offered by present-day lagoons compared with ocean patches in general seem to provide a likely explanation for the overwhelming importance of lagoonal gathering. Although foragers are quite willing to walk relatively long distances on the exposed intertidal lagoon flat (often in excess of overland distances to the ocean side), they also have more opportunities to increase their net energy acquisition rate across the various lagoon patches as the tide comes in and they are compelled to move closer to shore to the less-productive patches (but still more productive relative to the intertidal ocean patches).

\section{RESULTS}

\section{The Mollusk Harvest}

Twenty-four species of mollusks are the principal objects of foraging in the Gilbert Islands, with three species composing the bulk of the harvests. The relative dietary contributions of lagoonal shellfish from the intertidal beach to the lagoon slope on South Tarawa, derived from the SGS, are listed in Table 1. Thomas (1999) converted gross weights into edible meat weights using ratios presented. Protein and energy were calculated by multiplying the values per $100 \mathrm{~g}$, illustrated in Thomas (1999) by the total weight of the harvested mollusks (Table 1).

TABLE 1

Relative Dietary Contribution of Mollusks during 83 Lagoonal Gathering Trips on South Tarawa (in Rank Order According to Edible Meat)

\begin{tabular}{lccrr}
\hline \hline Species & No. of trips & Edible meat (kg) & Protein (kg) & Kcal \\
\hline Strombus l. & 59 & 93.89 & 18.31 & 79,807 \\
Anadara & 51 & 61.73 & 5.35 & 34,569 \\
Gafrarium & 42 & 1.00 & 0.68 & 3,748 \\
Asapbis & 5 & 0.66 & 0.08 & 393 \\
Atactodea & 3 & 0.62 & 0.10 & 498 \\
Quidnipagus & 2 & 0.40 & 0.04 & 255 \\
Tracbycardium & 11 & 0.07 & 0.04 & 186 \\
Strombus v. & 5 & 0.06 & 0.01 & 48 \\
Cymatium & 15 & 0.05 & 0.01 & 56 \\
Other & 12 & 0.03 & 0.003 & -15 \\
Spondylus & 2 & 0.004 & 0.001 & 3 \\
Timoclea & 1 & 0.004 & 0.001 & 3 \\
Pitar & 2 & & & \\
\hline
\end{tabular}


Strombus lubuanus Linnaeus, 1758. The strombid, te nouo, is common throughout much of the low intertidal and shallow subtidal areas of Tarawa Lagoon. It also occurs on sandbars with mixed sand and coral rubble that rise to within $0-2 \mathrm{~m}$ below the surface. Like other strombids, te nouo is an herbivore and feeds on algae attached to hard substrata (Abbott 1960). It often occurs in large colonies. Maturity is reached within $2 \mathrm{yr}$ after settlement, at which time shell length stabilizes at 40-60 mm, and the shell lip thickens. Adults are distinguished from juveniles by a distinct stromboid (anterior) and posterior notch (Poiner and Catterall 1988). Average edible weight is estimated at $2 \mathrm{~g}$.

Adults are usually epibenthic; juveniles tend to be buried in sediment. However, up to $30 \%$ of adults at Heron Island, Great Barrier Reef, were also buried, with an increase in this behavior during periods of inclement weather (Catterall and Poiner 1987, Poiner and Catterall 1988). Large numbers of mature individuals occur in deep water, with migration to shallower depths related to breeding. Like other strombids, te nouo can rapidly migrate from subtidal to intertidal areas by means of its powerful foot. In southern Papua New Guinea and eastern Australia, this strombid breeds from August to March and deposits up to 200,000 eggs. The planktonic larval stage may last between 2 and 3 weeks (Poiner and Catterall 1988).

Commercial exploitation occurs on $\mathrm{Ta}$ rawa, but at a smaller scale than that of the arcid te bun, Anadara uropygmelana. Te nouo is gathered by visually searching for exposed individuals, making no distinction between large and small shells or thin- and thicklipped shells. The annual harvest is estimated at $400 \mathrm{t}$ (Paulay 1995). Total edible weight stands at $85.2 \mathrm{t}$, with $16.61 \mathrm{t}$ of protein, and over 72 million kcal. Like most gastropods, te nouo are boiled in large metal pots over an open fire to facilitate meat extraction. The large, pointed operculum allows for relatively easy extraction with the fingers, whereas other gastropods usually require the use of a twig or metal pin. In the absence of stone, empty shells are occasionally utilized in earth ovens to heat up certain foods.
Anadara uropygmelana (Bory de SaintVincent, 1824). This arcid, te bun, is the most often-targeted mollusk in the central Gilberts, notably on South Tarawa where it occurs in low intertidal and subtidal regions of the lagoon (Figure 4). Unlike other anadarine bivalves, $A$. uropygmelana is attached to both hard and soft substrata by a slender byssus, even in its adult stage, although byssal threads were often lacking among te bun examined by Tebano (1990). Byssal attachment may be crucial in the early stages of its life history, with the root system of Thalassia hemprichii appearing to provide suitable surface. Individuals from depths of 2 to $8 \mathrm{~m}$ tend to be larger than those in the intertidal and are abundant in habitats with fine, soft substratum. Te bun reaches maturity at $38 \mathrm{~mm}$ in females and $42 \mathrm{~mm}$ in males (Tebano and Paulay 1995). Reports on traditional gathering practices from various geographical areas describe minimum shellfish length collected as $20-30 \mathrm{~mm}$ (Catterall and Poiner 1987). For South Tarawa the value is closer to $10 \mathrm{~mm}$ (Paulay 1995). Te bun yields about $4 \mathrm{~g}$ of edible meat in the lagoon reef flat, with a mean length of $45 \mathrm{~mm}$, and $8 \mathrm{~g}$ offshore for an average length of about $55 \mathrm{~mm}$.

These bivalves live half buried in sea grass beds where young individuals may escape detection in thick undergrowth. Like most bivalves, te bun is sedentary in its adult stage; consequently, replenishment of heavily exploited intertidal areas by reproductive individuals from the subtidal regions cannot take place. Little is known about larval biology or recruitment in this species. Tebano (1990) suggested that spawning may be continuous, with peaks during full moon. However, there is high spatiotemporal variability in recruitment. Thalassia may be important in larval settlement and development by providing a refuge from predation and acting as a buffer against wave action and currents, preventing settled recruits from being swept away.

The bivalves are located in the intertidal zone by a telltale slit in the sand marking their presence. Offshore diving for te bun is confined to Tarawa. There are reports from South Tarawa of te bun artificially buried in 


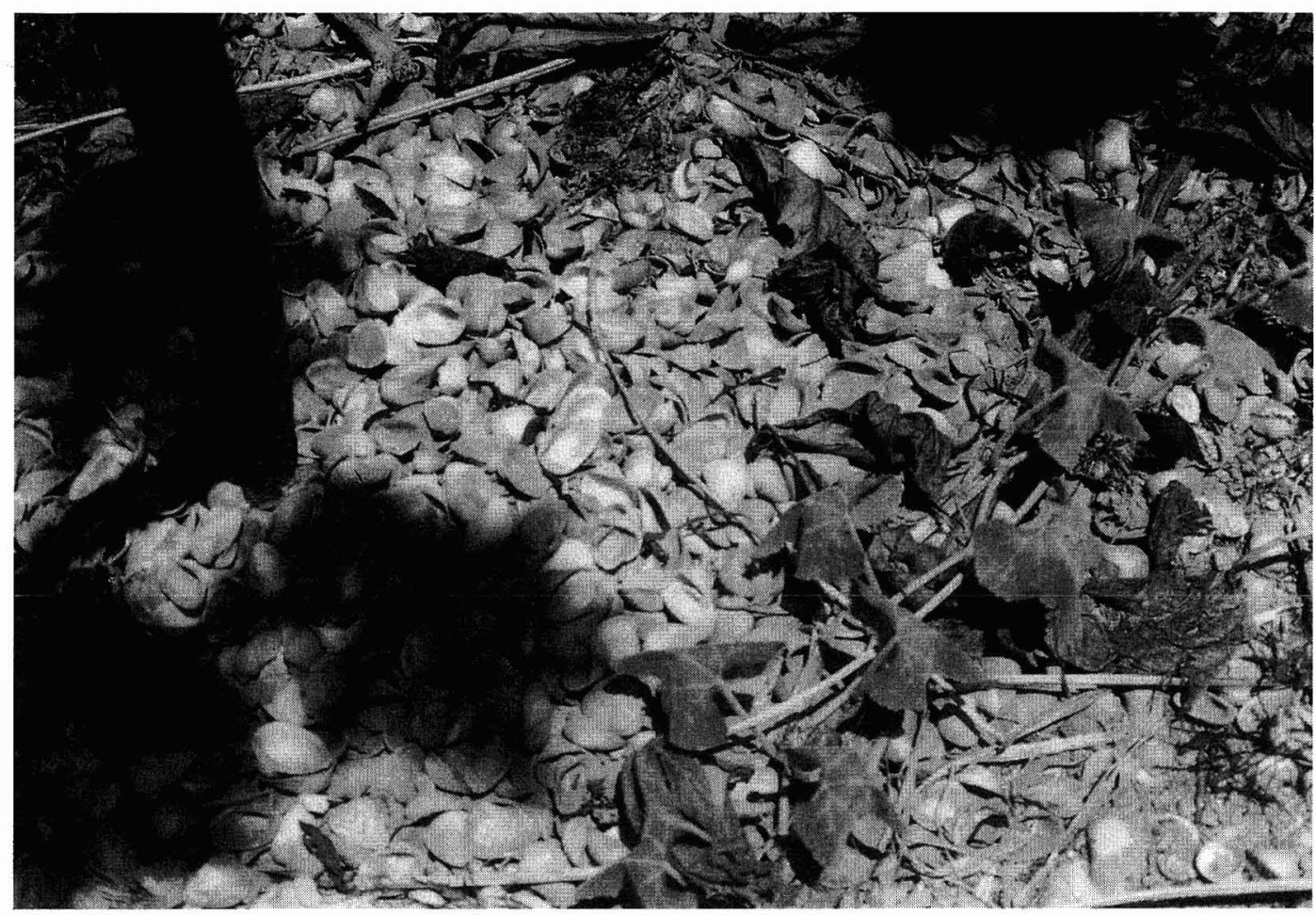

Figure 4. Anadara midden, Tebanga Village, Maiana (photo by F. Thomas).

sand and surrounded by large rectangular coral enclosures near the lagoon shore, similar to those of the tridacnid gardens (Zann 1985).

Yearly harvest of te bun gathered offshore from Tarawa Lagoon, including export to Majuro and Nauru, has been estimated at $1000 \mathrm{t}$, with an additional $370 \mathrm{t}$ taken from sand flats and sea grass beds (Paulay 1995). The figures translate into $217.83 \mathrm{t}$ of edible meat, $25.92 \mathrm{t}$ of protein, and more than 121 million kcal. It should be noted that these figures are not consistent with the rank order in Table 1, where Strombus lubuanus, te nouo, exceeds te bun in all categories. Diver counts, average weight of the daily catch, and the estimated number of days when diving is possible (about 275 days per year excluding the traditional day of rest, Sunday, and the average duration of stormy weather), however, indicate that te bun is harvested in greater numbers than those reported in the SGS, where sampling error is suspected. Paulay (1995) noted an increase in te bun densities from sea grass $(42,000$ specimens per ha, $\mathrm{SD}=68,000)$ to lagoon slope $(78,000$ specimens per ha, $\mathrm{SD}=136,000)$. For the highly mobile te nouo, mean densities of 14,000 specimens per ha, $\mathrm{SD}=59,000$, and 67,000 specimens per ha, $\mathrm{SD}=191,000$, were reported for sea grass and lagoon slope, respectively.

Te bun with perforated umbo were recovered archaeologically and may have functioned as paring knives (Takayama et al. 1990). I was informed that shells with holes knocked through the top of the valve are currently used as supports for the alga $E u$ chema. Perforations may also result from predators, such as the gastropod Cymatium muricinum (Tebano and Paulay 1995). The opportunistic use of discarded valves to scale 


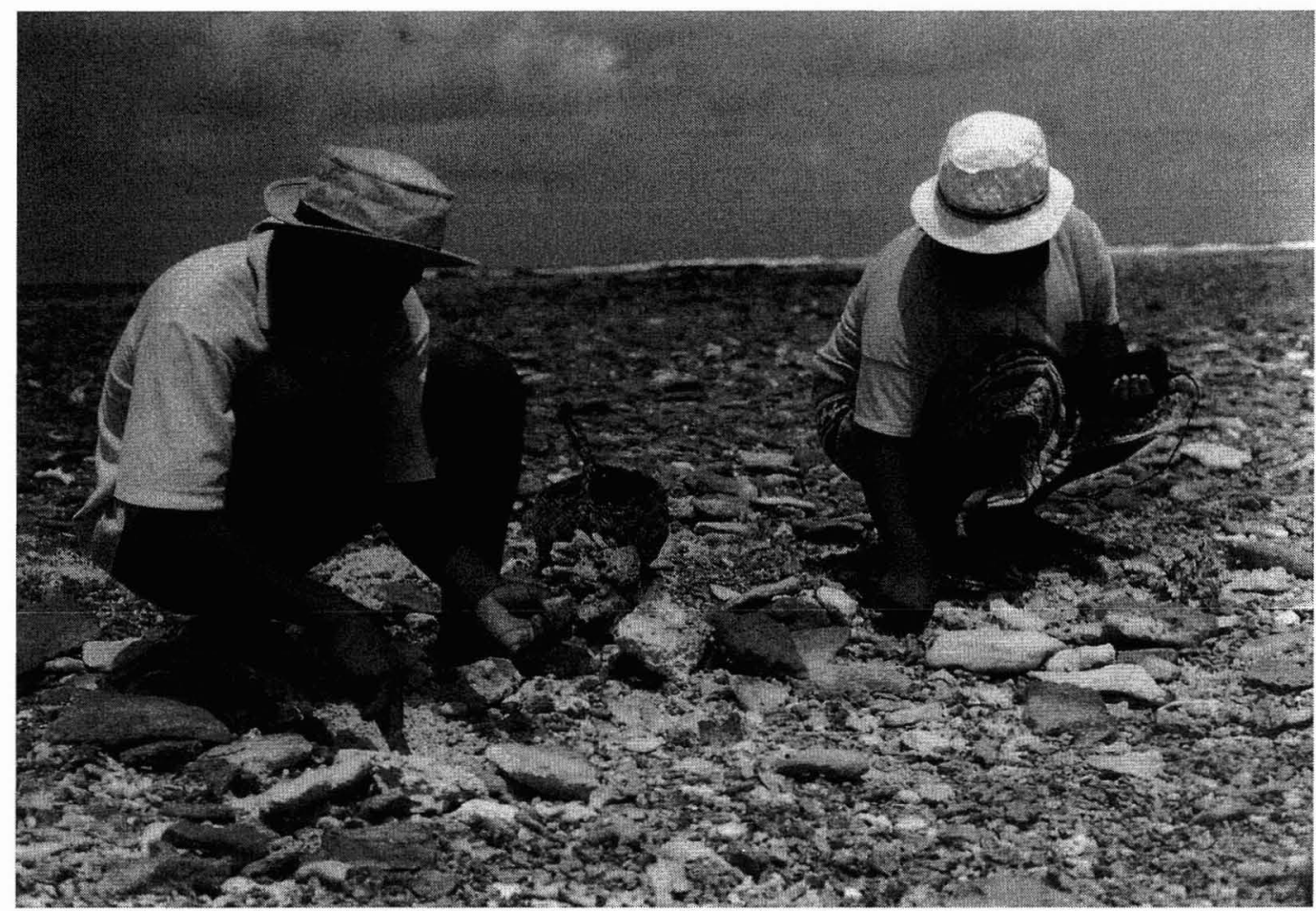

Figure 5. Digging for Asaphis, Kariatebike, Abemama (photo by F. Thomas).

fish and for grating coconut meat was also noted. Like te nouo, the shells of te bun are used as heating surfaces in earth ovens.

Gafrarium pectinatum Linnaeus, 1758. This venerid, te koumara, is found in a variety of settings, from shallow, silty environments of the intertidal to sea grass beds and sandbars. These gastropods mature at a shell length of between 16 and $20 \mathrm{~mm}$, reaching a maximum length of just over $35 \mathrm{~mm}$ (Morton 1990). It yields just under $1 \mathrm{~g}$ of edible meat at about $27 \mathrm{~mm}$ in length (Yamaguchi et al. 1993). Te koumara is found buried up to $15 \mathrm{~cm}$ deep in the sand, has sedentary subtidal populations, and reproduces at a low level throughout the year, with seasonal peaks during spring and fall in Hong Kong mangroves (Morton 1990). The planktonic larval stage probably lasts 3 to 4 weeks (see Catterall and Poiner 1987). Except in the BonrikiTemaiku area, this species is rarely the focus of gathering on South Tarawa. Nevertheless, it remains an important secondary catch, with an annual harvest estimated at $45 \mathrm{t}$ (Paulay 1995), representing $3.92 \mathrm{t}$ of edible meat, $0.52 \mathrm{t}$ of protein, and close to 3 million $\mathrm{kcal}$. Te koumara was at the time of my investigations the prominent mollusk gathered by the people of Tebanga Village on Maiana, where systematic digging took place.

Asaphis violascens (Forskål, 1775). The psammobiid, te koikoi, is mainly an upper intertidal species, particularly common in gravely sands on both lagoon and ocean sides. The closely related or conspecific Asaphis deflorata, found in the western Atlantic, provides a model for the biology of te koikoi. The bivalve matures at a length of $25 \mathrm{~mm}$ or greater and may attain a length of $77 \mathrm{~mm}$ (Berg and Alatalo 1985). Average edible weight is estimated at $9 \mathrm{~g}$. This psammobiid burrows in sand to a depth of $30 \mathrm{~cm}$. Mass 
spawning occurs in late summer and the larval stage is about 2 weeks (Berg and Alatalo 1985). Where te koikoi is abundant, harvesting involves systematic digging (usually with spoons) (Figure 5). They are also harvested by visually searching the sand for the siphonal openings. Te koikoi, and the tellinid Quidnipagus palatam, te nikatona, must be carefully processed before consumption: the valves are individually opened with a knife, the sandy stomach extracted, and the meat is washed in fresh water. Discarded valves are still occasionally used as scrapers for removing coconut meat. Te koikoi occurs in areas of the lagoon used for defecation (Paulay 1995) and may be somewhat protected for that reason. Nevertheless, on South Tarawa, te koikoi appears to be below the maximum length that may be attained by the species, perhaps as a result of overharvesting (mean $=53.3 \mathrm{~mm}$, $\mathrm{SD}=9.3, n=101)$.

Atactodea striata (Gmelin, 1791). The mesodesmatid, te katura, is abundant in sand on both leeward and windward beaches. The shell reaches maturity at about $20 \mathrm{~mm}$ and may grow to about $30 \mathrm{~mm}$ in length (Eisenberg 1981). Te katura is easily accessible, often buried at depths of less than $5 \mathrm{~cm}$. The species has an extended breeding period, with peaks during the summer months in New Caledonia (Baron 1992). Te katura is among the smallest edible mollusk gathered in Kiribati, with a meat weight of less than $1 \mathrm{~g}$. Because of high densities, however, large quantities can be collected in a narrow strip of sand.

Quidnipagus palatam (Iredale, 1929). The tellinid, te nikatona, appears restricted to the upper intertidal, both in gravely and silty sands. Mature individuals typically range in length between 44 and $70 \mathrm{~mm}$ (Eisenberg 1981). Mean length of specimens measured on Tarawa and Abemama is $45.5 \mathrm{~mm}$ $(\mathrm{SD}=7.4, n=85)$, with an average edible weight of about $3 \mathrm{~g}$. Individuals burrow in $20-30 \mathrm{~cm}$ of sand. Harvesting involves searching for the siphonal openings, systematically digging when densities are high, and excavating water-covered sand with sweeping hand motions. The presence of water reportedly facilitates digging.
Tracbycardiumangulatum (Lamarck, 1822). The cardiid, te koikointari, is found mainly in areas of Thalassia growth and on sandbars. Adults average $60 \mathrm{~mm}$ (Abbott and Dance 1982). Mean length recorded in the field is $60.4 \mathrm{~mm}(\mathrm{SD}=10.1, n=22)$. This species yields about $16 \mathrm{~g}$ of edible meat. A linear groove in the sand, similar to that of te bun, indicates the presence of buried cockles. However, they may be capable of moving about with short leaps engendered by their long foot, as do other Cardiidae (see Kay 1979). Informants say te koikointari used to be more abundant at Kariatebike, Abemama, than it is now, and it is considered rare. It is not known whether overharvesting caused this change or an environmental factor such as reduction in Thalassia cover.

Strombus variabilis athenius Duclos, 1844. The strombid, te newenewe, is reported from sandy lagoon flats, but was most often noted on the seaward reef flat where sand occurs, and in mangrove-covered passages just below the low-water mark. The species ranges in length between 27 and $43 \mathrm{~mm}$ (Abbott 1960). Specimens measured on Tarawa average $41.9 \mathrm{~mm}$ ( $\mathrm{SD}=7.9, n=40)$. Edible meat weight is about $2 \mathrm{~g}$. Many of the attributes described for Strombus lubuanus such as rapid maturity, high mobility, a long planktonic stage, and great capacity for dispersal may also be applicable in this species. Numerous shells from my archaeological excavations on Abemama display a broken-off spire, presumably to extract the meat. The identified pattern may indicate uses other than for human consumption, however. According to local sources, te newenewe damaged in this way may reflect meat extraction for use as fish bait, notably for bonefish, te ikari, Albula glossodonta. A similar explanation may account for the missing spires among other gastropods, such as te wiaau, Cymatium muricinum.

Cymatium muricinum (Röding, 1798). The ranellid, te wiaau, is found in sandy lagoons at both low intertidal and subtidal depths. It is also reported from the deeper portions of seaward reef flats (Demond 1957). Maturity is reached when the shell attains a length of about $25 \mathrm{~mm}$ (Eisenberg 1981). Average edible weight is estimated at $1 \mathrm{~g}$. The larval 
stage may last up to 4 weeks (Clench and Turner 1957). As with most gastropods, this prey type is boiled in the shell and the meat pulled from the aperture. However, among the archaeological remains found on Abemama, there is a consistent pattern of shell breakage with the spire missing. This pattern may indicate that the animal was eaten raw or that part of the shell was broken off after it was cooked (Thomas 1999).

Spondylus squamosus Schreibers, 1793. The spondylid, te koikoinanti, lives firmly attached to dead coral in intertidal and shallow subtidal regions on the ocean side of the motu and in the lagoon where it is found on sandbars. Average adult length is $100 \mathrm{~mm}$ (Abbott and Dance 1982); mean length of local specimens is $75.2 \mathrm{~mm}(\mathrm{SD}=10.3, n=$ 6) with an average of $10 \mathrm{~g}$ of edible meat. Although sedentary, large te koikoinanti are often difficult to locate because of the heavy deposition of marine growth on the valves that blends with the environment. The shell was the preferred species for pendants, which were kept as heirlooms (Koch 1986).

Timoclea marica (Linnaeus, 1758). The venerid, te koumai, inhabits sand flats and sea grass beds on the lagoon reef flat and the lagoon floor. Te koumai is usually buried under a few centimeters of sand, although some live individuals were found on the sand surface completely exposed at low tide. The species matures at between 15 and $20 \mathrm{~mm}$ (Dance 1976). Mean length of Kiribati specimens is $20.6 \mathrm{~mm}(\mathrm{SD}=1.9, n=40)$, with a meat weight of less than $1 \mathrm{~g}$. Like te koumara, the planktonic larval stage may be 3 to 4 weeks (Catterall and Poiner 1987).

Pitar prova (Conrad, 1837). The venerid, te nikabibi, occurs in sand flats and sea grass beds and may extend farther offshore. Adults average $40 \mathrm{~mm}$ (Abbott and Dance 1982). Mean length for Kiribati is $33.8 \mathrm{~mm}$ (SD = $8.8, n=16$ ), with an average meat weight of about $2 \mathrm{~g}$. Attributes of this species' life history and habitat information may be inferred from those of other venerids, te koumara and te koumai.

Nerita plicata (Linnaeus, 1758). The neritid, te kaban, occurs in the high intertidal zone on beachrock and high-level conglom- erates. The gastropod matures at about $20 \mathrm{~mm}$ in $4 \mathrm{yr}$ and may attain $30 \mathrm{~mm}$ (Richard 1982). The Kiribati samples have a mean length of $12.2 \mathrm{~mm}(\mathrm{SD}=1, n=20)$, with an average weight of less than $1 \mathrm{~g}$. Te kaban is most active at night when it feeds upon surface algae. During the day, it may find refuge in crevices, where it avoids desiccation. As an archaeogastropod, one would expect poor dispersal potential and a restricted range. However, $N$. plicata is very common throughout the Indo-Pacific, from East Africa to as far east as Hawaili and Clipperton (Demond 1957). The widespread distribution of a species that would otherwise be expected to remain within the relatively narrow confines of the local environment may relate to population dynamics over evolutionary time scales. For both molluscan and fish populations (Leis 1994, Paulay 1996), it seems likely that if species find habitat-related refugia during glacial regressions, their ranges would be fragmented.

Nerita polita Linnaeus, 1758. Despite differences in shell morphology, average size, and habitat preference, all neritids are referred to as te kaban. $N$. polita is a high intertidal species found in sand pockets adjacent to cemented features and in upper layers of gravely sands. Adults are between 20 and $40 \mathrm{~mm}$ in length (Eisenberg 1981). The mean for Kiribati is $22.3 \mathrm{~mm}$ in length (SD $=2, n=23$ ), with an edible meat weight of just under $1 \mathrm{~g}$. During the day, the gastropod remains buried about $2.5 \mathrm{~cm}$ deep in sand. At dusk, it emerges from the sand and feeds on algae occurring on cemented features (Demond 1957). Like Nerita plicata, this neritid is widespread in the Indo-Pacific.

Polinices tumidus (Swainson, 1840). The naticid, te tumara, occurs in intertidal sand flats and sandbars. Individuals are typically between 25 and $75 \mathrm{~mm}$ in length (Eisenberg 1981). Mean length in field specimens is $31.9 \mathrm{~mm}(\mathrm{SD}=4.1, n=40)$, with an average weight of $3 \mathrm{~g}$. As a mesogastropod, it may have a relatively long larval stage with good dispersal potential. Te tumara is usually harvested when the sand is thoroughly exposed at low tide and the gastropod's characteristic track is clearly visible. The animal moves 
quickly with the aid of a large foot, plowing up sand as it feeds. The snail marks its presence by a ridge at one end of the track, where it can be dug less than $5 \mathrm{~cm}$ below the surface. The naticid is primarily exploited for its shell to make dancing belts (Koch 1986).

Polinices melanostomus (Gmelin, 1791). This naticid, also termed te tumara, occurs in the same habitat as $P$. tumidus, in intertidal sand flats and sandbars. It differs from $P$. $t u$ midus in having a smaller size range and is readily distinguishable by its dark brown columella (the columella is white in P. tumidus [Kay 1979]). Adults range between 18 and $46 \mathrm{~mm}$ (Eisenberg 1981), and average weight is about $2 \mathrm{~g}$.

Oliva miniacea Röding, 1798. The olivid, te burebangaki, shares the same habitat as te tumara in the sand flats and sandbars. This species is one of the largest of the olive shells, with lengths approaching $100 \mathrm{~mm}$. Maturity is usually reached at $50 \mathrm{~mm}$, but may also occur at a length of less than $40 \mathrm{~mm}$ among dwarf populations (Petuch and Sargent 1986). Mean length for Kiribati samples is $53 \mathrm{~mm}$ $(\mathrm{SD}=4, n=24)$, with an average edible weight of $4 \mathrm{~g}$. Larvae probably develop rapidly, as would be expected for neogastropods. These sand dwellers also leave well-defined tracks in the sand and lie just beneath the surface at a spot usually marked by a ridge with small cracks. Olives are carnivorous and especially active at night (Eisenberg 1981), although no night foraging activities for this species were documented. The shells of te burebangaki are occasionally strung together as dancing belts.

Barbatia foliata (Forskål, 1775). The arcid, te nikarinei, is found attached to dead coral in shallow areas of the lagoon. There is little information on this species. Adults average $50 \mathrm{~mm}$ in length (Abbott and Dance 1982); in Kiribati mean length is $53.1 \mathrm{~mm}$ ( $\mathrm{SD}=16.2, n=28$ ), with an average of just under $4 \mathrm{~g}$ of edible meat.

Vasum turbinellum (Linnaeus, 1758). The vasid, te nimakaka, is gathered from the windward reef flats and is common in tide pools. Populations extend at least as far as the reef margin. Adults are typically between 44 and $85 \mathrm{~mm}$ in length (Abbott 1959). Mean length of individuals gathered on Abemama is $37.9 \mathrm{~mm}(\mathrm{SD}=3.5, n=20)$, with an average meat weight of less than $1 \mathrm{~g}$. As with most Neogastropoda, it may be assumed that the free-swimming larval stage is relatively brief.

Turbo setosus Gmelin, 1791. The turbinid, te nimitanin, is mainly found on the reef crest (Richard 1982). Adults are usually between 40 and $60 \mathrm{~mm}$ long, occasionally exceeding $90 \mathrm{~mm}$, and yield about $4 \mathrm{~g}$ of edible meat (Demond 1957). The free-swimming stage among turbans is short, with larvae remaining for less than a week as plankton (Yamaguchi 1989). Subsequent growth is relatively slow, with individuals attaining $95 \%$ of the shell height in $5 \mathrm{yr}$ (Villiers and Sire 1985). These gastropods are more accessible during low spring tides than at neap tides when people can walk greater distances across the seaward reef flat. At full moon, they reportedly migrate from their shelter in coral cracks to the surface. Shells may also be gathered from fish traps, where they find suitable habitats between coral slabs. Freshly caught individuals are boiled in the shell to release the solid, calcareous operculum. Banner and Randall (1952) noted that the shell was also broken and the animal eaten raw. A small portion of the meat was commonly used for fish bait (Cooper 1964). Some of the perforated shells excavated on the northernmost island of Makin may have been used as paring knives or net sinkers (Takayama and Takasugi 1988).

Hermit crabs, te makauro, Coenobita perlatus, commonly find refuge in empty te nimitanin shells and are gathered for consumption. The activity is nocturnal, usually occurring along windward beaches in and around strand vegetation. Some hermitted shells can be distinguished by their eroded appearance both inside and out. However, archaeological sites containing operculae suggest that at least some of the shells were gathered for their resident gastropod, rather than for crab meat.

Lambis lambis (Linnaeus, 1758). The strombid, te ang, is the most common and one of the most widely distributed species of Lambis, ranging between 92 and $200 \mathrm{~mm}$ in length (Abbott 1961). The mean shell length 
in the Abemama sample, albeit from a small sample, is $260 \mathrm{~mm}(\mathrm{SD}=30.3, n=4)$. Meat weight averages $280 \mathrm{~g}(\mathrm{SD}=61.5, n=43)$. $\mathrm{Te}$ ang lives in colonies from the low-tide zone to depths of about $3 \mathrm{~m}$ on sand adjacent to leeward reefs. Yamaguchi (1989) reported a larval stage of about 3 weeks and juveniles that grow fairly rapidly on small algae. One informant on Abaiang claimed that te ang remains mostly buried during the first and last quarters of the moon phase. Te ang is collected by men, who must dive for it. It is most often roasted in the shell, which is then broken up and the animal removed, but the dorsal section of the shell may also be broken with a hammer and the strombid eaten raw.

Tridacna maxima (Röding, 1798). This bivalve, te were, is one of four species of giant clams found in the Gilberts. It occurs on reef structures, partly embedded in coral or firmly attached to coral heads by byssal threads throughout its adult life. Te were is not fully mature until it attains a shell length of 60$80 \mathrm{~mm}$ (Munro 1993). Amount of edible meat is more variable than in some of the other species examined, with an average of $33 \mathrm{~g}(\mathrm{SD}=27, n=30)$. Spawning may be continuous near the equator (Munro 1989). Despite very high fecundity, tridacnid larvae suffer considerable losses during their brief 6to 12-day planktonic period, with populations maintaining themselves primarily through local recruitment (Alcazar and Solis 1986). Te were is often firmly attached and is commonly dislodged by puncturing the adductor muscle and prying the animal free of its byssus before the valves shut. Older individuals tend to grow out of their coral matrix, easing the task of detaching the shells. Like other species of giant clams, they were used traditionally to manufacture adzes, but were quickly replaced by metal tools once they became available. Empty shells are still used for mashing leaves for local medicines. Giant clams are regularly exported from Abaiang to Tarawa. They are also important in the subsistence economy of Tabiteuea.

Tridacna gigas (Linnaeus, 1758). This giant clam, te kima, is the largest living species of bivalve, attaining a shell length of over $1 \mathrm{~m}$ and weighing in excess of $200 \mathrm{~kg}$. As with other tridacnids, amount of meat is highly variable, with a mean of $1050 \mathrm{~g}(\mathrm{SD}=250$, $n=7)$. This species is generally found on sand among corals on shallow reefs to a depth of about $20 \mathrm{~m}$. Compared with other species of giant clams, te kima grows rapidly to maturity, producing eggs at about $500 \mathrm{~mm}$ (Munro 1993). Large specimens are capable of releasing hundreds of millions of eggs in a single day, but with reductions in the number of mature individuals, the proportion of eggs that are not fertilized increases dramatically (Tekinaiti 1990). During their week-long free-swimming period, larvae suffer high mortality rates (Heslinga and Fitt 1987).

As with te bun and te ang, diving for te kima is a task accomplished by men. For large specimens, a steel anchor pole may be used to pierce the adductor muscle or an oar prevents the valves from closing before the muscle is cut with a bush knife, releasing the valves. The meat is scraped out of the shell, which may be left in place or carried home.

Small specimens $(<40 \mathrm{~cm})$ are occasionally transferred to shallow lagoon reef flats or deposited in passes adjacent to households. In place, they are allowed to grow until ready for consumption. This custom has been observed in other oceanic communities (see Moir 1989, Foster and Poggie 1993, Hviding 1993). Like fish traps, and areas used for Euchema farming, giant clam gardens are the property of individual households, whereas the reef flat on both lagoon and ocean sides is now regarded as common property. Giant clam gardens are marked by a circular coral enclosure about $40 \mathrm{~cm}$ high, coral rubble, or fish trap. A few are not marked at all. Concentrations in the gardens range from one or two specimens to larger aggregates; they may consist of large individuals, but more commonly small bivalves are used. Because of pilferage in populated areas, giant clam gardens are now confined to relatively isolated locations, such as the motus of the leeward reef. The gardens are disappearing from the Kiribati seascape, however, in large part as a reflection of the erosion of customary marine tenure. Owners are now less inclined to continue to care for giant clams in designated lagoon sections or to invest in maintaining 


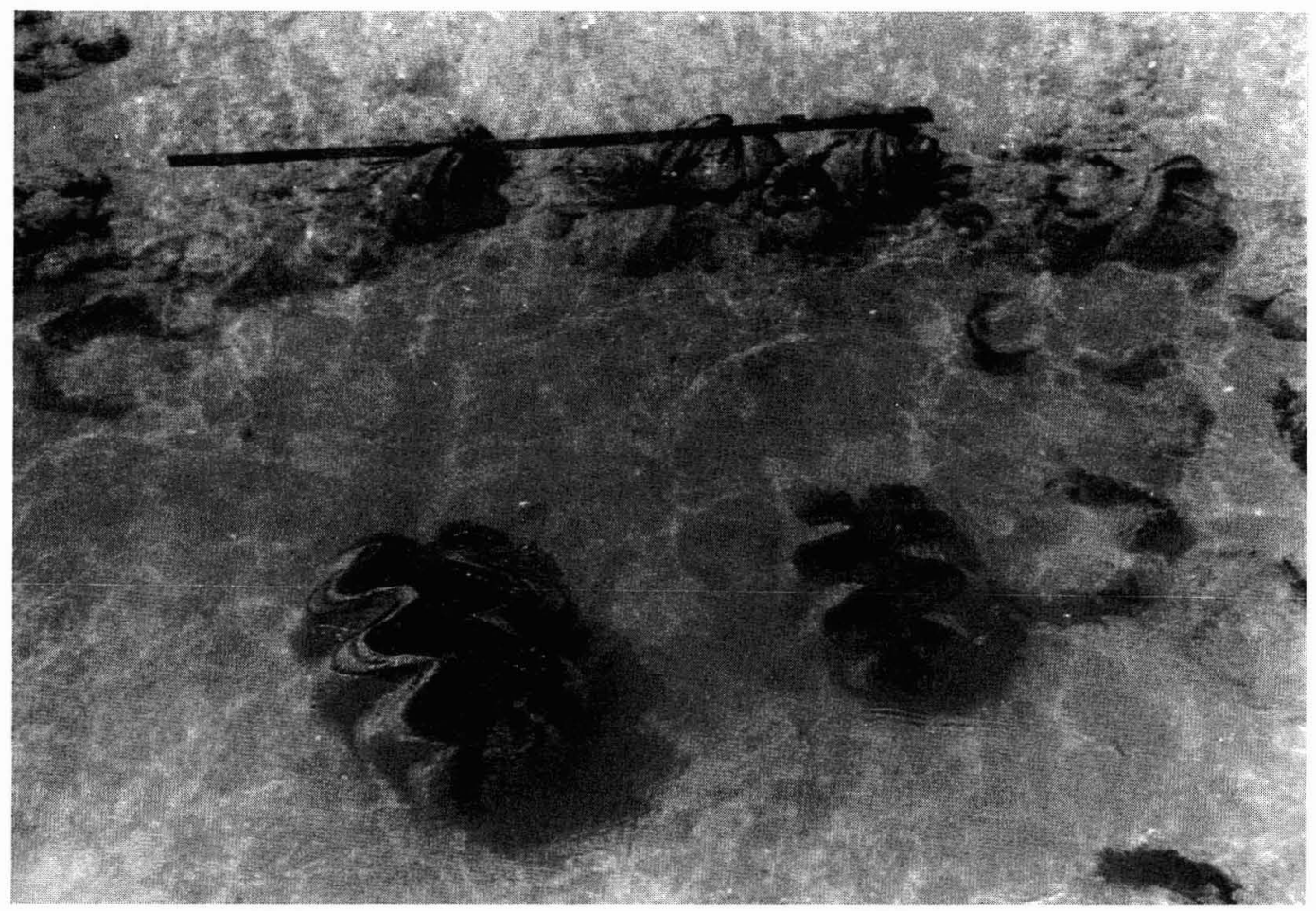

Figure 6. Giant clam "garden” (Tridacna gigas, Hippopus bippopus), Abatiku, Abemama (photo by F. Thomas).

large fish traps (Figure 6). Informants claim that both te kima and te neitoro, Hippopus bippopus, from the gardens are harvested only during periods of inclement weather, when fishing is difficult or when no other meat source is available. Taniera (1988) reported that they were also consumed at feasts.

Te kima provided the raw material for adzes, chisels, gouges, and scrapers (Takayama et al. 1990), and the shell was apparently used as a container for cooking (Catala 1957). Contemporary uses of empty te kima valves include troughs for feeding pigs, for crushing certain foods, and as shrine components. Te kima gathering, whether for immediate or delayed consumption, is usually incidental to other activities, such as spearfishing, and may at times become a risky venture, if the fisherman is near a leeward pass where strong currents and large marine predators may be present.

Hippopus bippopus (Linnaeus, 1758). The giant clam, te neitoro, is found on sandy substrata in intertidal areas to depths of about $10 \mathrm{~m}$. Maturity is attained at a length of about $140 \mathrm{~mm}$ or when the shell is no longer attached to coral rubble. Edible meat weight averages $156 \mathrm{~g}(\mathrm{SD}=316, n=26)$. Like te were and te kima, the larval stage is short. Settlement of larvae usually occurs within a week after fertilization (Alcala et al. 1986). Te neitoro is often found in shallow, nearshore patches, where it may be completely exposed during spring low tides. Under these conditions, the valves are shut tight, and the animal is nearly camouflaged in the midst of dead coral. Neap tides, when the mantle is visible, provide the best opportunities to spot these bivalves. Like te kima, te neitoro gathering is normally incidental to other fishing activities, but it may become a focal prey type, particularly in some sections of the leeward reef platform at low tide where foragers are able to walk on the reef. The shells were used 
as ax and adze blades, hammerstones, and containers, the last continuing today (Koch 1986, Takayama and Takasugi 1988). Live specimens were also placed in lagoon gardens with te kima.

\section{DISCUSSION}

The degree of lagoon closure plays an important role in determining the number of species that can be found (Salvat 1969, 1972, Kay 1971, 1978, Kay and Switzer 1974). These patterns may not apply in the case of Tarawa and other open atolls influenced by nutrient-rich waters of the equatorial upwelling area, resulting in unusually high molluscan population densities, together with high species diversity (Paulay 1995).

A substantial rise in mollusk consumption has occurred on South Tarawa, a phenomenon linked to changes in water circulation when causeways were built in the 1960s, encouraging the establishment of certain species and increased fertilization by sewage-driven nutrients. Filter feeders exposed to contaminated water may become agents of gastrointestinal diseases, particularly if consumed raw or partially cooked (Danielson et al. 1995). It appears that shellfish contamination resulted in the abandonment of enclosures.

In Kiribati, communities target a limited range of marine invertebrates, although molluscan catches often include several species, which appear as incidental harvests. Paulay (1995) found that Strombus lubuanus, Anadara uropygmelana, and Gafrarium pectinatum occurred in 67,59 , and $47 \%$, respectively, of the South Tarawa sand flat and sea grass catches, but $61 \%$ of the catches were dominated (that is constituting greater than $75 \%$ of gross catch weight) by $S$. lubuanus and $26 \%$ by $A$. uropygmelana. The current observed and interview data confirm the importance of these species, with $A$. uropygmelana, S. lubuanus, and $G$. pectinatum occurring in 60,59 , and $33 \%$ of sand flat and sea grass catches, respectively. Seventy-eight percent of the catches have dominant species (as defined above, except that weight is for edible meat), with $A$. uropygmelana (19\%), S. lubuanus $(53 \%)$, and $G$. pectinatum (28\%). The inclu- sion of other species may give the impression that although foragers are targeting certain prey, they essentially gather all those that they consider edible. In her study of Australian Aboriginal subsistence, Meehan (1982) addressed some of the factors leading to a departure from targeting a single mollusk species. Some of her explanations appear sensible, for example, differences in foraging ability among participants, but her conclusion that among the Anbarra shell gathering is essentially a random process is in sharp contrast to Bird's (1996) demonstration among the Meriam of Torres Strait that shell-gathering activities can be explained in terms of the variable costs and benefits that foragers face while collecting prey.

The significance of size at maturity lies in its relationship with size below which individuals are rejected by foragers. A population will always contain reproducing individuals if size at maturity is less than the rejection size. However, the population is at risk if size at maturity exceeds the rejection size. Some targeted individuals may escape detection if they find refuge by burying themselves. A depleted intertidal population may be replenished through recruitment of individuals from adjacent subtidal areas that are usually inaccessible to traditional gatherers. Reproductive individuals with partially subtidal distributions may migrate into the exploited intertidal zone if they are mobile during their benthic stages. If the duration of the larval stage is sufficiently long, then it is possible for larvae spawned by more distant unexploited populations to settle into the exploited areas.

Prey resilience provides an alternative explanation for the apparent balance between traditional societies and their resources (Catterall and Poiner 1987, Poiner and Catterall 1988). According to the tenets of human behavioral ecology (Cronk 1991, Smith and Winterhalder 1992), if people are behaving to maximize their short-term harvest rate and vulnerable species fall in the optimal diet, a diminished-returns curve, as assumed in the "marginal value theorem" (MVT) (Charnov 1976), could lead to overexploitation and extinction of prey, though this is admittedly less likely than with a step-function curve (where 
the expected or marginal harvest rate suddenly drops to zero). However, if a given patch type has a very high return curve relative to other patch types, and some of the prey types in that patch type are not resilient to overexploitation, human foragers following the MVT are quite capable of causing local extinction. With the most vulnerable prey gone or greatly reduced in number, most remaining species presumably possess biological attributes that make them resilient to human predation. Unfortunately, little is known of the response of many tropical mollusk populations to gathering practices, in part at least because of the paucity of detailed information on life history and ecology (Catterall and Poiner 1987, Wells 1989, Munro 1999). Although it has not been possible to compile detailed information for every prey type, certain species are clearly at risk of depletion, even following a regime of traditional gathering.

The influx of human populations from the outer islands to Tarawa, together with a high birth rate, has resulted in the decline (in size and abundance) of easily accessible intertidal resources, particularly te bun, which is often the main source of protein for unemployed and low-income families. During the 19931994 field season, the roadside sale of te bun gathered offshore was putting pressure on stocks on Tarawa that were once relatively well protected from harvesting. Divers possessing a floating device (e.g., canoe, rubber inner tube) and goggles could collect large quantities of the bivalve on a daily basis and sell their catch in rice bags holding up to $34 \mathrm{~kg}$ of te bun. With approximately $16 \mathrm{mil}-$ lion te bun taken annually (before 1995), and an estimated population of 40 million in the heavily fished Taborio-Bangantebure bed, or 70 million from Nanikai to Bikenibeu, the harvest represented about one-third to onefifth of the total adult te bun population. These figures suggested that harvests were near, if not exceeding, sustainable rates (Paulay 1995).

According to Tebano (1990), reef blasting of Maiana's leeward reef opposite Raweai Village may have contributed to the recent disappearance of te bun in that area. Changes in water circulation associated with strong currents may have disturbed the nutrient-rich substratum inhabited by these bivalves and larvae washed away. The extent of these disturbances on overall te bun stocks is difficult to assess, but the paucity of small individuals $(<20 \mathrm{~mm})$ in other areas surveyed by Tebano suggests a decline in population densities. Informants at Tebanga, about $8 \mathrm{~km}$ from Raweai, also stated that te bun were considerably less abundant compared with a few years ago. With less pressure on lagoonal resources, Abemama's te bun stocks are not in apparent danger of reduced recruitment, and densities of more than 20 individuals per meter are said to be fairly common. Tebano (1990) reported that exploitation mainly took place during periods of inclement weather when fishing was hazardous.

Te nouo are conspicuously absent at Maiana and none was located in surface middens. Older informants did not recall a time when this species was present. Because habitats suitable for this gastropod exist, it may be that the absence of the species is linked to chance dispersal or local extinction, resulting in its discontinuous distribution (see Kay 1995). The resilience of te nouo to traditional gathering tends to rule out overexploitation. In contrast to Maiana, the strombid is fast becoming the dominant molluscan species in Tarawa Lagoon, perhaps as a consequence of the demise of many reefs linked to changes in sedimentation (Paulay 1995). The high variability of species density in sea grass beds reported by Yamaguchi et al. (1993) (254,000/ ha) and Paulay (1995) $(14,000 /$ ha) may reflect increasing gathering pressure, but could also be attributed to patchy distribution, perhaps linked to the species' high mobility. Nevertheless, a small average shell length for Tarawa sand flats (mean $=42.9 \mathrm{~mm}, \mathrm{SD}=4.9$, $n=206)$ may indicate harvesting pressure. On Yap, Kay and Smalley (1989) reported a mean length of $47.9 \mathrm{~mm}$ (range, 41-54, $n=18)$. Size range in the Pacific is $32.2-$ $69.5 \mathrm{~mm}$, with an average of $56.5 \mathrm{~mm}$ (Abbott 1960).

Current and future leaders will continue to be challenged by the often conflicting goals of implementing policies conducive to economic 
development and of assuring sustainable use of the environment. The second goal could be achieved by applying extant TEK for new biological and ecological insights for protected areas and for conservation education, for development planning and environmental assessment, and of course for resource management (see Berkes 1993).

The linkage between TEK and resource management, expressed through various forms of tenurial systems, has received considerable attention in the past few decades (Crocombe 1989, Johannes 1989). Many problems remain, however, in implementing TEK to serve conservation initiatives and related goals. In addition, there is the challenge of how TEK and scientific information can be integrated, and whether such integration is desirable, given unequal power sharing in decision making. The fisheries sector in Kiribati has been described as both a source of essential livelihood at the subsistence level and as a means to achieve greater economic independence by promoting the country's seemingly vast store of marine resources. The impressive number of feasibility studies, with an emphasis on finfish (Gillett et al. 1991), should furnish data for making informed choices.

The sustainability of mollusk fisheries in Kiribati rests in large part on a remodeled form of marine tenure (Johannes and Yeeting 1995). To achieve this goal, local fishers should be encouraged to pursue activities to generate income that could at the same time provide a means to ensure the long-term use of selected high-value resources, such as pearl shell and giant clam farming, using a combination of traditional knowledge and modern technology. Mollusks are especially suited to efforts aimed at establishing limited entry, because they are mostly sedentary and relatively predictable. Therefore, those resources are most economically defendable by various cooperative units already engaged in community projects.

\section{ACKNOWLEDGMENTS}

I thank my doctoral committee members, $\mathrm{P}$. Bion Griffin, E. Alison Kay, Harry Ako,
Terry L. Hunt, W. Bruce Masse, and Leslie E. Sponsel, for their guidance and comments on the dissertation from which this paper stems.

\section{Literature Cited}

Abbott, R. R., and J. Garcia, eds. 1995. Management plan for Tarawa Lagoon, Republic of Kiribati. Vol. III. Management plan. BioSystems Analysis, Inc., Santa Cruz, California.

Abbott, R. T. 1959. The family Vasidae in the Indo-Pacific. Indo-Pac. Mollusca 1 (1): 15-32.

1960. The genus Strombus in the Indo-Pacific. Indo-Pac. Mollusca 1 (2): 33-174.

- 1961. The genus Lambis in the IndoPacific. Indo-Pac. Mollusca 1 (3): 147174.

Abbott, R. T., and S. P. Dance. 1982. Compendium of seashells. E. P. Dutton, New York.

Alcala, A. C., E. P. Solis, and S. N. Alcaza. 1986. Spawning, larval rearing and early growth of Hippopus bippopus (Linn.) (Bivalvia: Tridacnidae). Silliman J. 33:45-53.

Alcazar, S. N., and E. P. Solis. 1986. Spawning, larval development and growth of Tridacna maxima (Bivalvia: Tridacnidae). Silliman J. 33:65-73.

Banner, A. H., and J. E. Randall. 1952. Preliminary report on marine biology study, Onotoa Atoll, Gilbert Islands. Atoll Res. Bull. 13:1-62.

Baron, J. 1992. Reproductive cycles of the bivalve molluscs Atactodea striata (Gmelin), Gafrarium tumidum and Anadara scapha (L.) in New Caledonia. Aust. J. Mar. Freshwater Res. 43:393-402.

Berg, C. J., and P. Alatalo. 1985. Biology of the tropical bivalve Asaphis deflorata (Linn., 1758). Bull. Mar. Sci. 37:827-838.

Berkes, F. 1993. Traditional ecological knowledge in perspective. Pages 1-9 in J. T. Inglis, ed. Traditional ecological knowledge: Concepts and cases. International Development Research Centre, Canadian Museum of Nature, Ottawa.

Bird, D. W. 1996. Intertidal foraging strategies 
among the Meriam of the Torres Strait Islands, Australia: An evolutionary ecological approach to the ethno-archaeology of tropical marine subsistence. Ph.D. diss., University of California, Davis.

Catala, R. L. A. 1957. Report on the Gilbert Islands: Some aspects of human ecology. Atoll Res. Bull. 59:1-187.

Catterall, C. P., and I. R. Poiner. 1987. The potential impact of human gathering on shellfish populations, with reference to some NE Australian intertidal flats. Oikos 50:114-122.

Cernohorsky, W. O. 1971. Marine shells of the Pacific. Pacific Publications, Sydney.

. 1972. Marine shells of the Pacific. Vol. II. Pacific Publications, Sydney.

Charnov, E. L. 1976. Optimal foraging: The marginal value theorem. Theor. Popul. Biol. 9:129-136.

Clench, W. J., and R. D. Turner. 1957. The family Cymatiidae in the western Atlantic. Johnsonia 3:189-244.

Cloud, P. E. 1952. Preliminary report on the geology and marine environments of Onotoa Atoll, Gilbert Islands. Atoll Res. Bull. 12:1-73.

Cooper, M. J. 1964. Ciguatera and other marine poisoning in the Gilbert Islands. Pac. Sci. 18:411-440.

Crocombe, R. G. 1989. Tomorrow's customary tenure in relation to conservation. Pages 21-27 in South Pacific Regional Environment Programme. Report of the workshop on customary tenure, traditional resource management and nature conservation. South Pacific Commission, Noumea.

Cronk, L. 1991. Human behavioral ecology. Annu. Rev. Anthropol. 20:25-53.

Dance, S. P. 1976. The collector's encyclopedia of shells, 2nd ed. McGraw-Hill, New York.

Danielson, R. E., R. R. Abbott, W. J. Kimmerer, and K. Etauti. 1995. Microbiological contamination of water and shellfish in Tarawa Lagoon, Kiribati: Remediation strategies for contaminated shellfish. In R. R. Abbott and J. Garcia, eds. Management plan for Tarawa Lagoon,
Republic of Kiribati. Vol. III. Management plan. BioSystems Analysis, Inc., Santa Cruz, California.

Demond, J. 1957. Micronesian reef-associated gastropods. Pac. Sci. 11:275-341.

Eisenberg, J. M. 1981. Seashells of the world. McGraw-Hill, New York.

Foster, K. B., and J. J. Poggie Jr. 1993. Customary marine tenure and mariculture management in outlying communities of Pohnpie [sic] State, Federated States of Micronesia. Ocean Coast. Manage. 20:122.

Gillett, R., M. Pelasio, and E. Kirschner. 1991. Kiribati fisheries bibliography. FAO/UNDP Regional Fishery Support Programme, Suva.

Gillie, R. D. 1993. Coastal erosion problems in the Gilbert Islands Group, Republic of Kiribati. SOPAC Technical Report No. 167. Suva.

Heslinga, G. A., and W. K. Fitt. 1987. The domestication of reef-dwelling clams. BioScience 37:332-339.

Hviding, E. 1993. The rural context of giant clam mariculture in Solomon Islands: An anthropological study. ICLARM Technical Report No. 39. Manila.

Johannes, R. E. 1989. Criteria for determining the value of traditional marine tenure systems in the context of contemporary marine resource management in Oceania. Pages 29-32 in South Pacific Regional Environment Programme. Report of the workshop on customary tenure, traditional resource management and nature conservation. South Pacific Commission, Noumea.

Johannes, R. E., and B. Yeeting. 1995. IKiribati knowledge and traditional management of lagoon resources. In R. R. Abbott and J. Garcia, eds. Management plan for Tarawa Lagoon, Republic of Kiribati. Vol. III. Management plan. BioSystems Analysis, Inc., Santa Cruz, California.

Kay, E. A. 1971. The littoral marine molluscs of Fanning Island. Pac. Sci. 25:260-281.

- 1978. Molluscan distribution patterns at Canton Atoll. Atoll Res. Bull. 221:159-170. 
1979. Hawaiian marine shells: Reef and shore fauna of Hawaii. Bishop Museum Press, Honolulu.

- 1995. Diversification and differentiation: Two evolutionary patterns in the molluscan fauna of the Pacific Islands with consequences for conservation. Pages 3753 in A. C. Brugen, S. M. Wells, and Th. C. M. Kemperman, eds. Biodiversity and conservation of the Mollusca: Proceedings of the Alan Solem memorial symposium on the biodiversity and conservation of the Mollusca. Backhuys, Oegstgeest-Leiden.

Kay, E. A., and S. Johnson. 1987. Mollusca of Enewetak Atoll. Pages 105-146 in D. M. Devaney, E. S. Reese, B. L. Burch, and P. Helfrich, eds. The natural history of Enewetak Atoll. Vol. II. Biogeography and systematics. U.S. Department of Energy, Office of Energy Research, Office of Health and Environmental Research, Ecological Research Division, Oak Ridge, Tennessee.

Kay, E. A., and T. L. Smalley. 1989. On the feasibility of a shell trade for the State of Yap. Pacific Business Center Program, University of Hawai'i, Honolulu.

Kay, E. A., and M. F. Switzer. 1974. Molluscan distribution patterns in Fanning Island lagoon and a comparison of the mollusks of the seaward reefs. Pac. Sci. 28:275295.

Koch, G. 1986. The material culture of Kiribati. Translated by Guy Slatter. Institute of Pacific Studies, University of the South Pacific, Suva.

Leis, J. M. 1994. Coral sea atoll lagoons: Closed nurseries for the larvae of a few coral reef fishes. Bull. Mar. Sci. 54:206227.

Meehan, B. 1982. Shell bed to shell midden. Australian Institute for Aboriginal Studies, Canberra.

Moir, B. G. 1989. Mariculture and material culture on Takuu Atoll. Ph.D. diss., University of Hawai'i at Mānoa, Honolulu. University Microfilms International, Ann Arbor, Michigan.

Morton, B. 1990. The life cycle and sexual strategy of Gafrarium pectinatum (Bivalvia:
Veneridae) in a Hong Kong mangrove. Malacol. Rev. 23:53-62.

Motteler, L. S. 1986. Pacific Island names. Bishop Mus. Misc. Publ. 34.

Munro, J. L. 1989. Fisheries for giant clams (Tridacnidae: Bivalvia) and prospects for stock enhancement. Pages 541-558 in J. F. Caddy, ed. Marine invertebrate fisheries: Their assessment and management. John Wiley \& Sons, New York.

-1993. Giant clams. Pages 431-449 in A. Wright and L. Hill, eds. Nearshore marine resources of the South Pacific: Information for fisheries development and management. Institute of Pacific Studies, University of the South Pacific, Suva.

. 1999. Utilization of coastal molluscan resources in the tropical insular Pacific and its impacts on biodiversity. Pages $127-$ 144 in L. G. Eldredge, J. E. Maragos, P. F. Holthus, and H. F. Takeuchi, eds. Marine and coastal biodiversity in the tropical island Pacific region. Vol. 2. Population, development and conservation priorities. Pacific Science Association, Honolulu.

Paulay, G. 1995. Benthic ecology and biota of Tarawa Lagoon: Influence of equatorial upwelling, circulation, and human predation. In R. R. Abbott and J. Garcia, eds. Management plan for Tarawa Lagoon, Republic of Kiribati. Vol. III. Management plan. BioSystems Analysis, Inc., Santa Cruz, California.

. 1996. Dynamic clams: Changes in the bivalve fauna of Pacific Islands as a result of sea-level fluctuations. Am. Malacol. Bull. 12:45-57.

. 1997. Benthic ecology and biota of Tarawa Lagoon: Influence of equatorial upwelling, circulation, and human predation. Marine Laboratory, University of Guam (revised paper, originally published 1995).

Petuch, E. J., and D. M. Sargent. 1986. Atlas of the living olive shells of the world. Coastal Education and Research Foundation, Fort Lauderdale, Florida.

Poiner, I. R., and C. Catterall. 1988. The effects of traditional gathering on populations of the marine gastropod Strombus lu- 
buanus Linne [sic] 1758, in southern Papua New Guinea. Oecologia (Berl.) 76:191199.

Richard, G. 1982. Mollusques lagunaires et recifaux de Polynésie française: Inventaire faunistique-bionomie-bilan quantitatif -croissance-production. Ph.D. thesis, Universite Pierre et Marie Curie, Paris.

Richmond, B. 1993. Reconnaissance geology of the Gilbert Group, western Kiribati. SOPAC Technical Report No. 77. Suva.

Salvat, B. 1969. Dominance biologique de quelques mollusques dans les atolls fermés (Tuamotu, Polynésie): Phénomènes récents-conséquences actuelles. Malacologia 9:187-189.

. 1972. La faune benthique du lagon de l'atoll de Reao (Tuamotu, Polynésie). Cah. Pac. 16:31-110.

Smith, E. A., and B. Winterhalder, eds. 1992. Evolutionary ecology and human behavior. Aldine de Gruyter, New York.

Takayama, J., and H. Takasugi. 1988. Archaeology on Makin, Kiribati, Central Pacific. Department of Ethnology, Tezukayama University, Nara-shi, Japan.

Takayama, J., H. Takasugi, and K. Kaiyama. 1990. Test excavation of the Nukantekainga site on Tarawa, Kiribati, Central Pacific. Pages 1-19 in I. Ushijima, ed. Archaeological research on atoll cultures of Micronesia, 1988. University of Tsukuba, Tsukuba-shi, Japan.

Taniera, T. 1988. Status of giant clams in Kiribati. Pages 47-48 in J. W. Copland and J. S. Lucas, eds. Giant clams in Asia and the Pacific. ACIAR, Canberra.

- 1994. Traditional fisheries in Kiribati: Survival and sustainability. Pages 113-120 in J. Morrison, P. Geraghty, and L. Crowl, eds. Science of Pacific island peoples. Vol. I. Ocean and coastal studies. Institute of Pacific Studies, University of the South Pacific, Suva.

Tebano, T. 1990. Some aspects of population biology and ecology of the cockle Anadara maculosa in the Gilbert Islands, Republic of Kiribati. M.S. thesis, James Cook University, Townsville, Australia.

Tebano, T., and G. Paulay. 1995. Variable recruitment and changing environments create a fluctuating resource: The biology of Anadara uropygmelana (Bivalvia: Arcidae) in Tarawa. In R. R. Abbott and J. Garcia, eds. Management plan for Tarawa Lagoon, Republic of Kiribati. Vol. III. Management plan. BioSystems Analysis, Inc., Santa Cruz, California.

Tebano, T., T. Taniera, T. Tabe, and E. Taraku. 1993. Akawa ni Kiribati (Traditional fishing methods of Kiribati). Marine Studies Programme, University of the South Pacific, Suva.

Tekinaiti, T. 1990. Status of giant clam stock at the four atolls in Kiribati: Abaiang, Maiana, Tarawa, Abemama. Fisheries Division, Tarawa.

Thomas, F. R. 1999. Optimal foraging and conservation: The anthropology of mollusk gathering strategies in the Gilbert Islands Group, Kiribati. Ph.D. diss., University of Hawai'i at Mānoa, Honolulu. University Microfilms International, Ann Arbor, Michigan.

Villiers, L., and J.-Y. Sire. 1985. Growth and determination of individual age of Turbo setosus (Prosobranchia: Turbinidae), Hao Atoll (Tuamotu, French Polynesia). Proceedings of the Fifth International Coral Reef Congress, Moorea 5:165-170.

Wells, J. W. 1957. Coral reefs. Pages 609631 in J. W. Hedgpeth, ed. Treatise on marine ecology and paleoecology. Vol. 1. Ecology. National Research Council, National Academy of Sciences, Washington, D.C.

Wells, S. M. 1989. Impacts of the precious shell harvest and trade: Conservation of rare and fragile resources. Pages 443-454 in J. F. Caddy, ed. Marine invertebrate fisheries: Their assessment and management. John Wiley \& Sons, New York.

Yamaguchi, M. 1989. Report on a baseline study for fisheries development in Oceania, with special reference to sedentary organisms on coral reefs and lagoons. Department of Marine Sciences, University of the Ryukyus, Okinawa.

Yamaguchi, M., B. Yeeting, K. Toyama, T. Tekinaiti, and T. Beiatau. 1993. Report on a preliminary study of molluscan resources in Tarawa Lagoon, with special reference 
to te bun Anadara maculosa. Department of Marine Sciences, University of the Ryukyus, Okinawa.

Zann, L. P. 1982. The marine biology of Betio Island, Tarawa Atoll, Republic of Kiribati. Institute of Marine Resources, University of the South Pacific, Suva. . 1985. Traditional management and conservation of fisheries in Kiribati and Tuvalu atolls. Pages 53-77 in K. Ruddle and R. E. Johannes, eds. The traditional knowledge and management of coastal systems in Asia and the Pacific. UNESCO/Regional Office for Science and Technology for Southeast Asia, Jakarta. 